\title{
Studies on the Ripening of Plantains Under Controlled Conditions
}

\author{
F. Sánchez Nieva, I. Hernández, C. Bueso de Viñas ${ }^{1}$
}

\section{INTRODUCTION}

The industrial utilization of plantains in Puerto Rico is limited to the use of the green fruit to prepare fried plantain chips, frozen prefried slices, and in the preparation of specialty-type products in which plantain is an ingredient. Sánchez-Nieva and Hernández $(5)^{2}$ studied the preservation of ripe plantains in syrup by freezing. The stage of ripeness for processing was found to be one of the principal factors determining product quality. It became evident from the results of this work that commercial processing of ripe plantains would not be feasible unless the fruit is ripened to the desired stage under controlled conditions. This report deals with studies conducted to determine the proper factors for ripening plantains under controlled conditions.

\section{REVIEW OF THE LITERATURE}

The methods used for ripening bananas consist in general of placing the fruit in tight rooms in which temperature and relative humidity can be controlled. Ethylene is used to obtain uniform ripening. Commercial ripening practices in the United States, England, and Australia have been summarized by Simmonds (6). The temperature for ripening ranges from $70^{\circ} \mathrm{F}$. for fast ripening, to $60^{\circ}-58^{\circ} \mathrm{F}$. for slow ripening. The relative humidity is maintained at 90 to 95 percent during the early stage of the process and later reduced to 85 percent by ventilation. Ethylene is applied at the rate of 1 cubic foot per 1,000 cubic feet of room space in two to three doses at 12 to 24 hours intervals. Finishing of the fruit is carried out at $56^{\circ}-60^{\circ} \mathrm{F}$. at 80 to 85 percent relative humidity, with frequent air changes.

A comprehensive summary of the changes that take place during the ripening of bananas under controlled conditions is given by von Loesecke (7). Changes in starch, reducing and non-reducing-sugars, pectin and protopectin, and acidity, were measured at frequent intervals during ripening under controlled conditions in several varieties of bananas including plantains. The changes taking place during ripening can be summarized as

1 Associate Director, Agricultural Experiment Station, Assistant Chemical Engineer, and Assistant Food Technologist, respectively, Food Technology Laboratory, Agricultural Experiment Station, University of Puerto Rico, Mayagüez Campus, Río Piedras, P.R.

2 Number in parentheses refer to Literature Cited, pp. 528-9. 
follows: The predominant carbohydrate in the green banana is starch, which is converted to glucose, fructose and sucrose. The conversion of starch to sugars coincides with the respiration climacteric. There is a slight increase in the water content. The color of the fruit changes with the disappearance of the chlorophyl, turning yellow due to the presence of xantholyls and carotenes. Acidity rises to a maximum after the climacteric, and then drops. The softening of the pulp progresses with ripening, and the pulp:peel ratio increases.

\section{EXPERIMENTAL PROCEDURES}

The fruit used for these studies was harvested from experimental plots of the local plantain cultivars known as Guayamero and Maricongo grown at the Corozal Substation. The fruit was harvested at a predetermined age measured from flowering. In some experiments, fruit was purchased from farmers or bought at the local market place at the stage of maturity at which the fruit is commonly harvested.

To obtain preliminary data on ripening treatments, the fruit was ripened in the bunch inside 55-gallon steel drums provided with a loosely-fitted cover. The drums were placed in a walk-in ripening room with controlled temperature and humidity. Ethylene was applied when required at the rate of $1 / 1,000$ on a volume basis. Individual fruits were removed from the third hand for carbohydrate analyses and other chemical determinations.

Final ripening experiments were conducted in a ripening room of about 1,000 cubic feet with controlled temperature, humidity, and air flow. Ventilation was carried out through bunk doors with exhaust fans as required. Ethylene was applied at the rate of 1 cubic foot/1,000 cubic feet of room space. The bunches were placed in the room uncovered. In both types of experiments, when ethylene was used, the plantains were allowed to cool until the pulp temperature was close to the set room temperature, which usually required 24 hours. The single dose of ethylene was applied immediately after cooling.

Fruits from the third hand were removed for analyses. The fruit was weighed and peeled by hand. From the weights of pulp and peel, the pulp: peel ratio was calculated. All analytical determinations were made on the peeled fruit. Carbohydrates, acidity, and moisture are expressed on a freshpulp-weight basis.

Starch was determined by the method of Carter and Neubert (2). Reducing and total-sugars were determined by the Moyer and Holgate method (4), inverting with invertase for total-sugar determinations. Acidity and pH were measured by the A.O.A.C. glass-electrode method (3).

Texture was measured with the Lee-Kramer electrical recording and indicating press with a 5,000-pound proving ring, with the range set for 
2,000 pounds. The plunger was adjusted to move at $1.5 \mathrm{~mm}$. per second. A standard shear-cell was used for all determinations. To make a measurement, the plantains were peeled and cut in halves lengthwise, the slices were cut in length to fit the cell, and placed perpendicular to the path of the knives. The cell was packed full, which generally required about 8 ounces of the sliced fruit. The time force curve was recorded, and the area under the curve was measured with a planimeter. The maximum force applied was read directly from the chart.

\section{RESULTS AND DISCUSSION}

The preliminary ripening experiments were conducted by putting the bare bunches inside 55-gallon steel drums located in a ripening room with controlled temperature and relative humidity. The drums provided the

TABLE 1.-Preliminary data from ripening trealments using steel drums with room temperature set at $78^{\circ} \mathrm{F}$., $95-100$ percent relative humidily and no ventilation

\begin{tabular}{c|c|c|c|c}
\hline Trial number & $\begin{array}{c}\text { Ethylene } \\
\text { application }\end{array}$ & $\begin{array}{c}\text { Days in } \\
\text { ripening room }\end{array}$ & Color of peel & $\begin{array}{c}\text { Percent } \\
\text { ripe fruit }\end{array}$ \\
\cline { 2 - 3 } 1 & Once & 4 & $4-5$ & 100 \\
2 & do & 4 & $4-5$ & 100 \\
3 & do & 4 & $4-5$ & 100 \\
4 & do & 4 & $4-5$ & 100 \\
5 & None & 4 & $4-5$ & 100 \\
6 & do & 5 & $4-5$ & 50 \\
\hline
\end{tabular}

1 Color of peel was judged using the standard banana color chart (1).

advantage that individual bunches could be given different treatments without disturbing others. The void space in the drums provided an atmosphere similar to that surrounding bare bunches ripening in a normally loaded room.

Since plantains are known to ripen spontaneously at room temperature, some experiments were conducted to determine how the fruit ripens when no ethylene is applied. When no ethylene was used in one experiment (table 1), 100 percent of the plantains ripened evenly in 4 days, while in a second experiment only 50 percent of the bunches ripened within this period. In all experiments in which ethylene was applied, the fruit ripened evenly in 4 to 5 days.

Data from an experiment in which plantains at different stages of development (harvested at different ages) were ripened at $72^{\circ} \mathrm{F}$. without ethylene, and with one dosage of ethylene applied 24 hours after placing the fruit in the drums, is given in table 2 . The starch and sugar content was determined on the fourth day after entering the room. When no ethylene 
was used, a direct relationship was observed between age or stage of development of the fruit and degree of ripeness. Fruit ranging in age from 84 to 92 days remained green showing little, if any, indication of starch conversion to sugars. Fruit at a more advanced stage of development was turning by the third day. By the fourth day, the starch was already being converted to sugars.

TABLE 2.-Effect of the stage of development of plantains and ethylene application on the rate of ripening at $72^{\circ} \mathrm{F} .{ }^{1}$

\begin{tabular}{|c|c|c|c|c|}
\hline Age & Reducing sugars & Total sugars & Starch & Color of the peel \\
\hline \multicolumn{5}{|c|}{ Without ethylene treatment } \\
\hline Days & Percent & Percent & Percent & \\
\hline 84 & 0.78 & 5.80 & 38.7 & Green \\
\hline 84 & .20 & 6.19 & 38.5 & Do. \\
\hline 92 & 1.11 & 6.08 & 37.5 & Do. \\
\hline 92 & .68 & 5.99 & 38.3 & Do. \\
\hline 95 & 6.17 & 11.03 & 30.8 & Yellowish \\
\hline 99 & 6.02 & 12.43 & 25.5 & Do. \\
\hline 103 & 6.47 & - & 29.8 & Do. \\
\hline 105 & 8.77 & 14.50 & 27.8 & Do. \\
\hline
\end{tabular}

With ethylene treatment

\begin{tabular}{r|r|c|l|l}
\hline 84 & 9.85 & 20.33 & 21.5 & Yellowish \\
84 & 11.25 & - & 24.6 & Do. \\
92 & 8.30 & 15.27 & 27.5 & Do. \\
92 & 9.23 & 11.03 & 18.3 & Do. \\
95 & 7.69 & 13.82 & 20.4 & Do. \\
99 & 10.25 & 19.65 & 22.5 & Do. \\
102 & 6.40 & 19.95 & 20.0 & Do. \\
106 & 8.15 & 16.42 & 18.4 & Do. \\
\hline
\end{tabular}

1 Analytical data and color of peel for samples taken the fourth day after been placed in ripening rooms.

When ethylene was applied, the plantains ripened evenly, irrespective of the age or stage of development. Starch to sugar conversion proceeded at about the same rate as indicated by the values for starch, reducing and total-sugars in table 2.

In these preliminary experiments no ventilation was used. However, since the drums were opened regularly to remove the samples, some ventilation was unavoidable. In later experiments during which the ripening rooms were ventilated the day after applying ethylene, the plantains ripened evenly. As a precaution to avoid choking, in all further experiments the room was ventilated for 15 minutes the day after applying ethylene. 
To study the effect of temperature and age on ripening, the plantains were ripened in a walk-in ripening room with the temperature set to the desired limit and with a relative humidity of 95-100 percent. The results of these experiments are shown in table 3 . At $60^{\circ} \mathrm{F}$. only plantains at a fairly advanced stage of development ripened. Under these conditions, the ripening process was slow, taking about a week for the fruit to turn yellow. Similar results were obtained at $66^{\circ} \mathrm{F}$. It should be noted from the data in table 3 that at this temperature ripening proceeded at a slightly faster rate than at $60^{\circ} \mathrm{F}$.

Plantains ripened evenly at $68^{\circ} \mathrm{F}$. in a way similar to those ripened at, $72^{\circ} \mathrm{F}$. At both temperatures the plantains turned yellow in 4 days.

TABLE 3.-Effect of temperature and age on the ripening of plantains as indicated by the color of the peel

\begin{tabular}{c|c|c}
\hline Temperature, ${ }^{\circ} \mathrm{F}$. & Age in days & Days for peel to color yellow \\
\hline 60 & 85 & No ripening \\
& 96 & Do. \\
& 100 & 7 \\
66 & 106 & 6 \\
& 86 & No ripening \\
& 88 & Do. \\
& 100 & 6 \\
68 & 103 & 5 \\
72 & $100-105$ & 4 \\
& $73-115$ & 4 \\
\hline
\end{tabular}

Based on the data from these experiments the following ripening treatment was adopted as a standard procedure for all further experiments: The fruit was placed in the ripening room as soon as possible after harvesting. The temperature of the room was adjusted to $72^{\circ} \mathrm{F}$. with a relative humidity of 95-100 percent. Ethylene was applied on the second day at the rate of $1 / 1,000$ cubic feet. During the third day, the room was ventilated for 15 minutes by the use of an exhaust fan located in a bunk door near the ceiling. The fruit then was left undisturbed until it reached the desired stage of ripeness.

Plantains always ripened evenly in a large number of experiments when this ripening treatment was used. No effect of age on ripening was observed, verifying previous findings. When plantains of the cultivars Maricongo and Guayamero were ripened, both behaved in the same way, ripening uniformly in 4 to 5 days. Similar results were obtained from plantains bought at the local market which varied greatly in the stage of development and apparently of several types or cultivars. 
TABLE 4.-Physical and chemical characteristics of the fruit and pulp of planlains at different stages of ripeness. Fruit ripened at $7 \mathscr{L}^{\circ} \mathrm{F}$.

\begin{tabular}{|c|c|c|c|c|c|c|c|c|c|c|c|}
\hline \multirow{2}{*}{\multicolumn{2}{|c|}{ Characteristic measured }} & \multicolumn{10}{|c|}{ Days in ripening room } \\
\hline & & 1 & 2 & 3 & 4 & 5 & 6 & 7 & 8 & 11 & 12 \\
\hline \multicolumn{2}{|l|}{ Stage of maturity² } & \multicolumn{2}{|c|}{ GREEN } & \multicolumn{2}{|c|}{ TURNING } & \multicolumn{2}{|c|}{ RIPE } & \multicolumn{4}{|c|}{ OVERRIPE } \\
\hline & (percent) & 61.6 & 65.1 & - & 64.8 & 66.2 & 67.8 & 69.5 & 72.5 & 74.1 & 73.6 \\
\hline $\begin{array}{l}\text { Pulp:peel ratio } \\
\text { Texture (shear press maximum } \mathrm{f}\end{array}$ & force) & ${ }_{776}^{1.60}$ & $620^{1.88}$ & $45 \overline{3}$ & 124 & $8^{1.98}$ & $8^{2.10}$ & $\begin{array}{l}2.31 \\
89\end{array}$ & $\begin{array}{l}2.65 \\
110\end{array}$ & $\begin{array}{l}2.92 \\
68\end{array}$ & $\begin{array}{l}2.82 \\
-\end{array}$ \\
\hline Area of curve (square & e inches) & 3.00 & 2.49 & 1.86 & .51 & .36 & .31 & .36 & .48 & .25 & - \\
\hline Moisture & (percent) & 59.90 & 58.20 & 59.10 & 60.20 & 60.90 & 61.12 & 61.63 & 61.70 & 64.77 & 65.59 \\
\hline Starch & Do. & 29.50 & 27.10 & 16.84 & 7.92 & 1.00 & .10 & .00 & .00 & .00 & .00 \\
\hline Reducing sugars & Do. & .43 & 1.30 & 4.46 & 11.94 & 18.10 & 19.39 & 23.56 & - & 27.05 & 25.77 \\
\hline Non-reducing sugars as invert & Do. & 1.09 & 3.10 & 7.41 & 4.02 & 1.11 & 1.98 & .94 & - & .58 & 1.41 \\
\hline Total sugars as invert & Do. & 1.52 & 4.40 & 11.87 & 14.92 & 19.21 & 21.37 & 24.50 & 26.68 & 27.63 & 27.18 \\
\hline Acidity as anhydrous citric acid & Do. & .18 & .24 & .24 & .66 & .67 & .73 & .67 & .64 & .61 & .56 \\
\hline 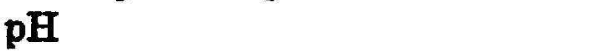 & & 5.90 & 5.65 & 4.86 & 4.52 & 4.43 & 4.37 & 4.34 & 4.45 & 4.57 & 4.50 \\
\hline
\end{tabular}

1 Judged from the color of the peel. 
These studies were extended to determine the composition of the pulp and the changes in texture which take place during ripening. The data gathered from these studies is given in table 4.

The course of the ripening process is best followed by plotting the conversion of starch to sugars against the days in the ripening room. The resulting graph is shown in figure 1. The conversion of starch to sugars started during the first day after the application of ethylene and proceeded rapidly during the next three days. By the fifth day, almost all the starch was converted to sugars. By the sixth day, the starch had almost disappeared completely. A rapid increase in reducing and total-sugars took place during the first 6 days, and then leveled off. Non-reducing sugars (table 4) decreased, reach-

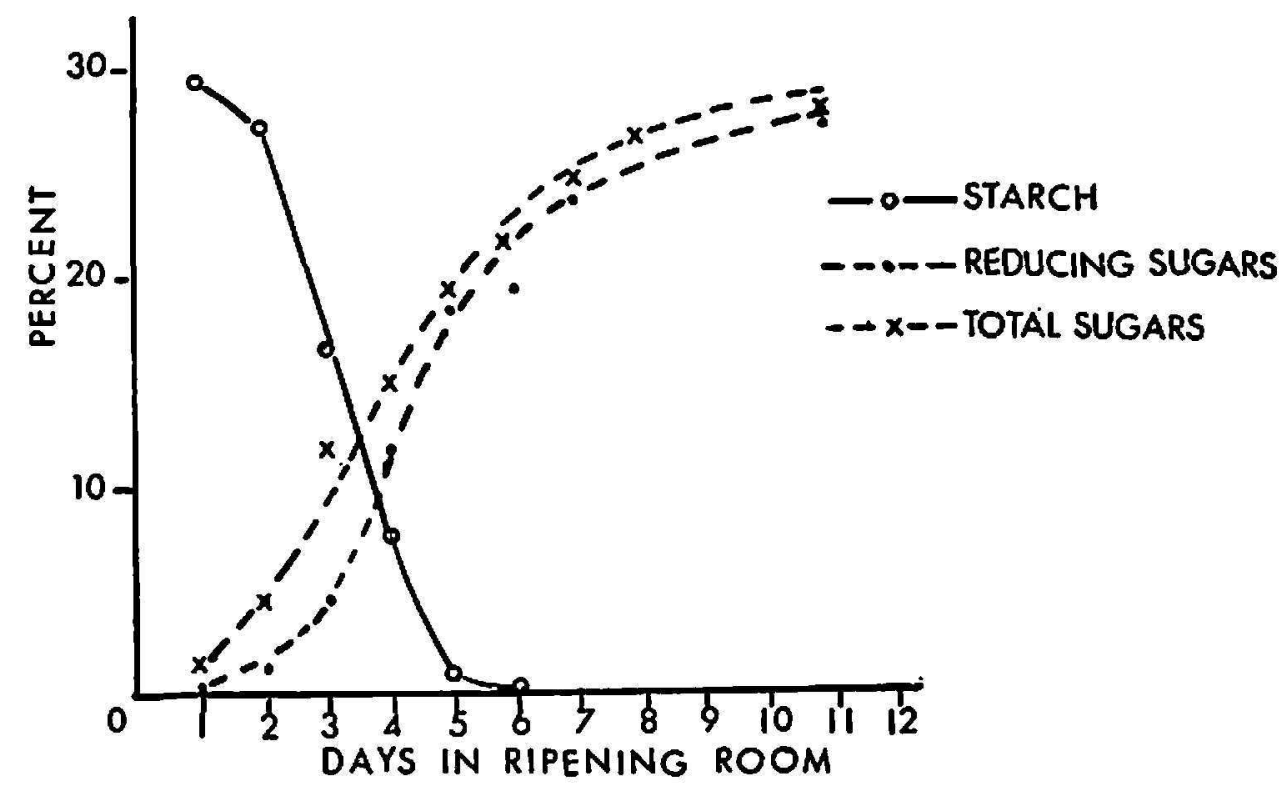

Frg. 1.-Conversion of starch to sugars during ripening of plantains at $72^{\circ} \mathrm{F}$.

ing a minimum value after the 7th day, indicating a complete inversion of the disaccharides.

The changes in pulp content, moisture, acidity, and $\mathrm{pH}$ during the ripening process are shown in figure 2 . The pulp content increased steadily from the green stage to the over-ripe stage. The moisture content of the pulp increased steadily during this period. The acidity increased to reach a maximum value by the sixth day, decreasing from then on. The $\mathrm{pH}$ decreased during the first six days, increasing again steadily to the overripe stage.

The changes in starch, reducing, non-reducing and total sugars in the pulp of the plantains during ripening are in accord with the changes reported by von Loesecke (7) for plantains ripened under controlled conditions. The total-sugars increased in 17 days from 0.82 to 21.10 percent. By the eleventh day in the ripening room the non-reducing sugars had disappeared completely. During this period the starch content decreased from 

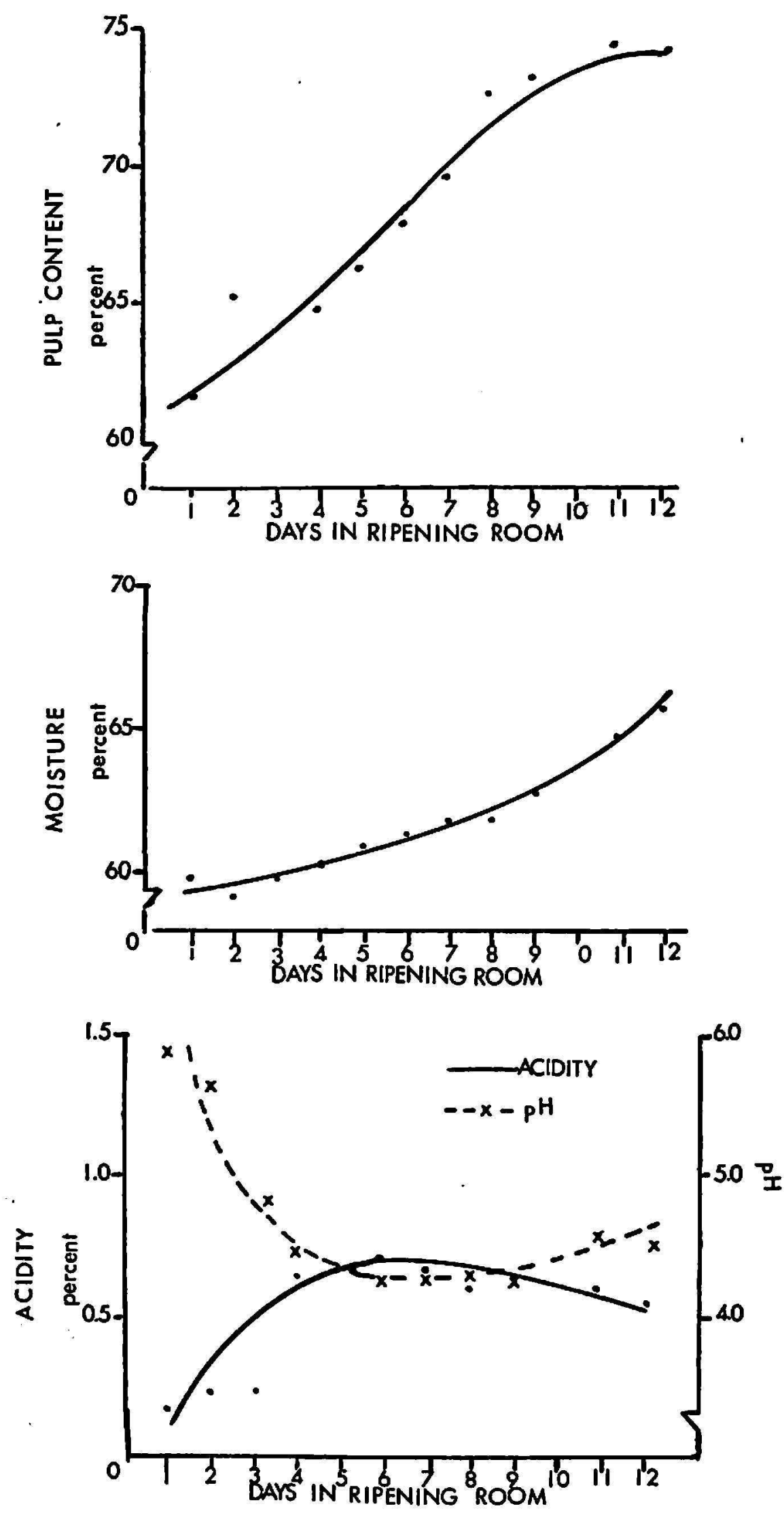

FIG. 2.-Changes in pulp content, moisture, acidity, and pH during ripening. 
an initial value of 32.2 percent of fresh pulp to 6.12. It should be noted that complete conversion of starch to sugars took place in 6 days in our work, while von Loesecke reports a higher starch content by the 17th day in which the fruit was at a "full-ripe" stage. Because the original work cited by von Loesecke was not available for consultation, it is presumed that a lower temperature was used for ripening which would account for a slower change in the starch content.

The changes in the texture of the pulp during the ripening process are shown by the data in table 4 and by the curve in figure 3 . The softening of the pulp proceeded rapidly to reach a minimum value by the fifth day. No further change in texture was observed from the fifth to the twelveth day

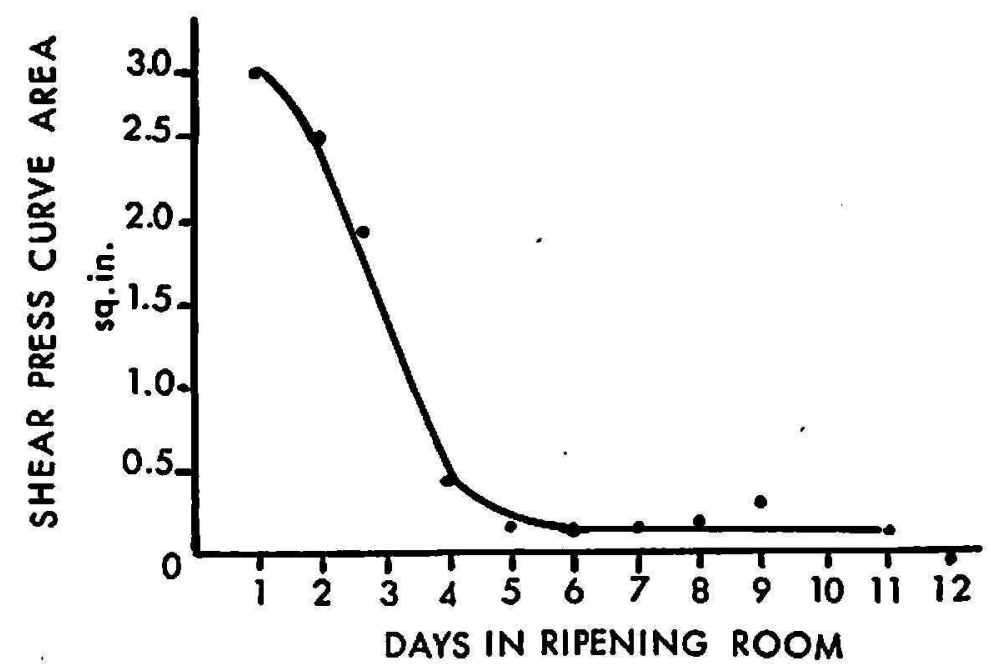

Fro. 3.-Changes in texture during ripening.

although by this time the fruit was overripe and the peel already was affected by anthracnose (fig. 4).

In a commercial ripening operation, the stage of ripeness will have to be judged from the color of the peel. A color chart for this purpose, similar to the one developed for bananas $(1,7)$, would be highly convenient. In developing such a color-chart, four definite stages of ripeness were selected: 1 , Green, 2, Turning, 3, Ripe, and 4, Overripe. The color of the peel for each of these stages is shown in figure 4. Physical and chemical characteristics for each stage are indicated in table 4 under the corresponding stage of ripeness. As previously indicated, the plantains were always ripe by the fifth day, but there may be an overlapping by the fourth day between the turning and ripe stages. Therefore, values for texture and chemical composition of the pulp of the ripe plantain may vary somewhat within the 4 to 5 day range.

In a study to develop a method for the preservation of ripe plantains in syrup by freezing, Sánchez-Nieva and Hernández (5) found that the 
highest quality product is obtained when fruit is used with a starch content of less than 4 percent. If fruit with a higher starch content is processed, the texture is hard and unacceptable. The data in table 4 shows that the average starch content of the pulp was 1.0 percent by the fifth day in the ripening room and that the sof!ening of the fruit had progressed to a point where pressure readings were at a minimum value. Fruit at this stage was found completely adequate for processing.

Because ripe plantains are widely used for cooking in Puerto Rico, the possibility exists that fruit can be ripened for the fresh market as well as for processing. The results of this work show that mature plantains ripen even at $60^{\circ} \mathrm{F}$. Experiments thus were conducted to determine the feasibility of holding ripe fruit at a lower temperature. Plantains with a starch content of about 4 percent were stored at $56^{\circ} \mathrm{F}$. and 85 percent relative humidity. Changes in texture, starch, sugars, acidity and $\mathrm{pH}$ were measured at frequent intervals. The results obtained are shown in table 5. The ripening process continued even at $56^{\circ} \mathrm{F}$., although very slowly. By the end of the sixth day in storage, the starch content decreased to 1.74 percent, the sugars increased by about 2 percent, the $\mathrm{pH}$ showed a slight trend to decrease, and the texture suffered no appreciable change. Although the fruit continued to ripen under storage, it remained for at least 6 days in excellent condition both for processing and for the fresh market.

\section{SUMMARY}

Studies were conducted to determine the proper conditions for ripening plantains for processing. The plantains ripened evenly in 4-5 days at $72^{\circ} \mathrm{F}$., 95-100 percent relative humidity, and with ethylene applied once at the rate of 1 cubic foot per 1,000 cubic feet of room space. Complete conversion of starch to sugars took place by the sixth day in the ripening room. At lower temperatures of $60^{\circ}$ to $66^{\circ} \mathrm{F}$, ripening proceeded at a much slower rate than at $72^{\circ} \mathrm{F}$., only very mature fruit ripening under these conditions. The physical and chemical characteristics of fruit ripening at $72^{\circ} \mathrm{F}$., are given for day-intervals from 1 to 12 days. A color chart is presented showing the peel color corresponding to the stage of ripeness at which the physical and chemical characteristics were measured.

When ripe fruit was stored at $56^{\circ} \mathrm{F}$, the ripening process continued at a very slow rate with the remaining starch being converted to sugars. At the end of 6 days in the ripening room, the fruit was still adequate for processing.

\section{RESUMEN}

Se llevó a cabo un estudio para determinar las condiciones más adecuadas para madurar el plátano con fines de elaboración. Los resultados obtenidos 


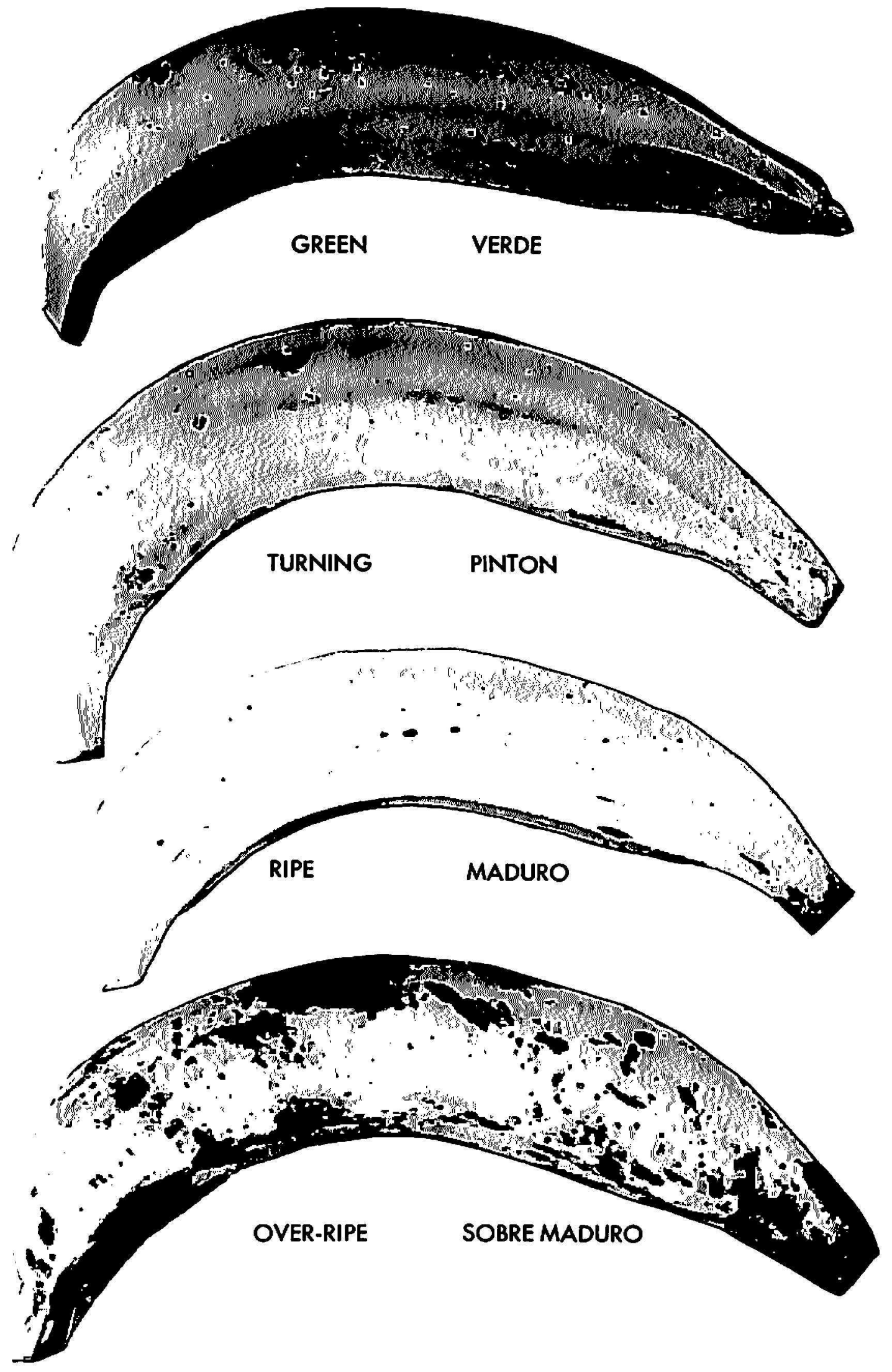

FIG. 4.-Peel color of plantains at different stages of ripeness. 
indican que la fruta madura muy bien en las cámaras de madurez a una temperatura regulada de $72^{\circ} \mathrm{F}$. y una humedad relativa de $95-100$ por ciento. Para que la fruta madure uniformemente es necesario hacer una aplicación de etileno en la proporción de 1 pie cúbico por cada 1,000 pies cúbicos de espacio en la cámara. El etileno se aplicó a las 24 horas de poner la fruta en la cámara, cuando la temperatura de la fruta era igual a la de la cámara. Bajo estas condiciones, la fruta maduró uniformemente en 465 áias, y al sexto día todo su contenido de almidón había quedado convertido en azúcares. Cuando los plátanos se maduraron sometidos a temperaturas de $60^{\circ}$ y $66^{\circ} \mathrm{F}$., el proceso de maduración procedió en forma muy lenta y sólo se maduraron aquellos que se cosecharon en un estado de desarrollo avanzado.

TABLE 5.-Changes in lexture and chemical properties of the pulp of ripe plantains stored at $56^{\circ} \mathrm{F}$.

\begin{tabular}{|c|c|c|c|c|}
\hline \multirow{2}{*}{ Characteristic measured } & \multicolumn{4}{|c|}{ Period of storage (days) } \\
\hline & 1 & 2 & 3 & 6 \\
\hline $\begin{array}{lr}\text { Texture } & \text { (shear press maximum force) } \\
\text { Area of curve } & \text { (square inches) } \\
\text { Starch } & \text { (percent) } \\
\text { Reducing sugars } & \text { Do. } \\
\text { Total sugars } & \text { Do. } \\
\text { Acidity as anhydrous citric acid } & \text { Do. } \\
\text { pH } & \end{array}$ & $\begin{array}{r}120 \\
.51 \\
4.11 \\
7.42 \\
28.75 \\
.75 \\
4.50\end{array}$ & $\begin{array}{r}100 \\
.49 \\
2.44 \\
10.52 \\
27.36 \\
.78 \\
4.53\end{array}$ & $\begin{array}{r}100 \\
.45 \\
1.64 \\
12.05 \\
29.72 \\
.72 \\
4.40\end{array}$ & $\begin{array}{r}120 \\
.54 \\
1.74 \\
8.94 \\
30.79 \\
.74 \\
4.10\end{array}$ \\
\hline
\end{tabular}

Se midieron las características químicas y físicas para indicar los cambios que tienen lugar en el contenido de la pulpa, en su textura, en el contenido de humedad, de acidez y de hidratos de carbono durante el proceso de maduración. Estas medidas se hicieron a intervalos frecuentes durante los 12 días que quedaron los plátanos en las cámaras. Para los distintos estados de madurez, se tomaron fotografías que indican el color de la cáscara y el estado de la fruta.

$\mathrm{La}$ fruta madura se almacenó a una temperatura de $56^{\circ} \mathrm{F}$. Bajo estas condiciones, el proceso de madurez continuó, convirtiéndose el almidón residual en azúcares. Después de un periodo de almacenamiento de 6 días, la fruta estaba aún en condiciones adecuadas para la elaboración.

\section{LITERATURE CITED}

1. Banana Ripening Manual, Circular No. 31, Fruit Dispatch Co., Boston, Mass., $32 \mathrm{pp} ., 1961$.

2. Carter, G. H., Neubert, A. M., Rapid Determination of Starch in Apples, J. Agr. Food Chem. 2 (21): 1070-72, 1954. 
3. Methods of Analysis of the Association of Official Agricultural Chemists, 9th ed., Washington, D.C., 272, 1960.

4. Moyer, J. C., and Holgate, K. C., Determination of alcohol-insoluble solids and sugar content of vegetables, Anal. Chem. 20 (5): 472-74, 1948.

5. Sánchez Nieva, F., and Hernández, I., Preparación y Conservación por Congelación de Plátanos Maduros en Almíbar, Agr. Exp. Sta Univ. P.R. Food Tech. Lab., Pub. 8, p. 8, 1967.

6. Simmonds, N. W., Bananas, Longmans, Green \& Co., Ltd., London, pp. 214-20, 1965.

7. Von Loesecke, H. W., Bananas, Interscience Publishers, Inc., New York, N.Y., pp. 67-118, 1949. 